\title{
PENGARUH PENDEKATAN LATIHAN DAN BERMAIN TERHADAP KEMAMPUAN PASSING BAWAH SEPAKBOLA PADA MAHASISWA
}

\author{
Sartono ${ }^{1,}$, Oman Hadiana ${ }^{2}$ \\ STKIP Muhammadiyah Kuningan \\ email: sartonoosh@yahoo.com
}

\begin{abstract}
Abstrak
Tujuan penelitian ini adalah untuk mengetahui: (1) Pengaruh pendekatan latihan dan bermain terhadap kemampuan passing bawah sepakbola pada mahasiswa putra Program Studi Pendidikan Jasmani Kesehatan dan Rekreasi Sekolah Tinggi Keguruan dan Ilmu Pendidikan Muhammadiyah Kuningan; (2) Metode yang lebih baik pengaruhnya antara pendekatan latihan dengan pendekatan bermain terhadap kemampuan passing bawah sepakbola pada mahasiswa putra Program Studi Pendidikan Jasmani Kesehatan dan Rekreasi Sekolah Tinggi Keguruan dan Ilmu Pendidikan Muhammadiyah Kuningan. Jenis penelitian yang digunakan adalah penelitian eksperimen. Subjek yang digunakan dalam penelitian ini adalah mahasiswa putra Program Studi Pendidikan Jasmani Kesehatan dan Rekreasi Sekolah Tinggi Keguruan dan Ilmu Pendidikan Muhammadiyah Kuningan yang terdiri dari 30 mahasiswa. Data yang dikumpulkan pada penelitian ini berupa data kemampuan passing bawah sepakbola. Teknik pengumpulan data yang digunakan adalah tes dan pengukuran kemampuan passing bawah sepakbola. Teknik analisis data yang digunakan dalam penelitian ini adalah uji perbedaan dengan melalui uji prasyarat yaitu uji reliabilitas, uji normalitas, dan uji homogenitas dengan taraf signifikansi 5 $\%$. Hasil penelitian diperoleh nilai perbedaan tes awal dengan t-test antara kelompok 1 dan kelompok 2 diperoleh nilai $t_{\text {hitung }} 1,00<t_{\text {tabel }} 2,145$. Berdasarkan hasil pengujian perbedaan tes akhir dengan t-test antara kelompok 1 dan kelompok 2 diperoleh nilai $t_{\text {hitung }} 2,712>t_{\text {tabel }} 2,145$. Berdasarkan hasil perhitungan persentase perbedaan kemampuan passing bawah sepakbola diketahui bahwa kelompok 1 memilki peningkatan sebesar 63,514\%. Sedangkan kelompok 2 memiliki peningkatan sebesar 40,789\%. Berdasarkan hasil penelitian dapat diperoleh simpulan sebagai berikut: (1) Ada pengaruh pendekatan latihan dan bermain terhadap kemampuan passing bawah sepakbola pada mahasiswa putra Program Studi Pendidikan Jasmani Kesehatan dan Rekreasi Sekolah Tinggi Keguruan dan Ilmu Pendidikan Muhammadiyah Kuningan, (2) Pendekatan latihan lebih baik pengaruhnya dibandingkan dengan pendekatan bermain terhadap kemampuan passing bawah sepakbola pada mahasiswa putra Program Studi Pendidikan Jasmani Kesehatan dan Rekreasi Sekolah Tinggi Keguruan dan Ilmu Pendidikan Muhammadiyah Kuningan.
\end{abstract}

Kata Kunci: Kemampuan, Passing, Sepakbola, Pendekatan

Abstract
This research aims to find out: (1) the difference between the effect of exercise and games
approach on the football passing undercapability on the male students of Physical Education,
Health, and Recreation Courses of Teaching and Learning College of Muhammadiyah
Kuningan, (2) the method is better taken effect between of exercise and games approach on the
football passing undercapability on the male students of Physical Education, Health, and
Recreation Courses of Teaching and Learning College of Muhammadiyah Kuningan.


Thisresearch employed an experimental. The subject of the research in the male students of Physical Education, Health, and Recreation Courses of Teaching and Learning College of Muhammadiyah Kuningan, as many as 30 students. The data collected in this research in the form on the football passing undercapability. The data collection techniques used is the test and measurement on the football passing undercapability. The data analysis technique used in this research is difference test with through prerequisite test that is reliability test, normality test, and homogeneity test with significance level of 5\%. The research result obtained the pre-test value differences with $t$-test between the group 1 and group 2 obtained $t_{\text {count }}$ value $1.00<t_{\text {table }}$ 2,145. Based on the result of the post-test differences test with t-test between the group 1 and group 2 obtained $t_{\text {count }}$ value 2,712 > $t_{\text {table }} 2,145$. Based on the result of the calculation on the percentage of the difference on the football passing undercapability known that the group 1 have increase of $63,514 \%$. While the group 2 have an increase of 40,789\%. Based on the result of the research done can be obtained drawing conclusions as follows: (1) there is a difference in does that of exercise and games approach on the football passing undercapabilityon the male students of Physical Education,Health, and Recreation Courses of Teaching and Learning College of Muhammadiyah Kuningan, (2) The exercise approach is better does that than with games approach on the football passing undercapabilityon the male students of Physical Education, Health, and Recreation Courses of Teaching and Learning College of Muhammadiyah Kuningan.

Keywords: Football, Passing, Capability, Approach

(C) 2017 STKIP Muhammadiyah Kuningan

PENDAHULUAN 
Sepakbola merupakan olahraga permainan yang cukup digemari oleh semua kalangan, dari kalangan anak-anak, dewasa, hingga orang tua hampir di seluruh negara di dunia termasuk Indonesia. Sepakbola adalah suatu permainan yang dimainkan oleh dua kelompok berlawanan yang masing-masing berjuang untuk memasukkan bola ke gawang kelompok lawan, yang dimana masing-masing kelompok beranggotakan sebelas pemain. Dibandingkan dengan cabang olahraga permainan lain, permainan sepakbola cukup popular jika dibandingkan dengan olahraga lainnya. Seperti dikemukakan Timo Scheunemann (2005: 15) bahwa, "Sepakbola pada saat ini adalah olahraga yang paling popular di dunia, jauh lebih popular dibandingkan olahraga popular lainnya seperti basket, volleyball, dan tenis". Sedangkan Beltasar Tarigan (2001: 1) menyatakan, "Sepakbola merupakan permainan beregu yang paling popular di dunia dan bahkan telah menjadi permainan Nasional bagi setiap Negara di Eropa, Amerika Selatan, Asia, Afrika dan bahkan pada saat ini permainan itu digemari di Amerika Serikat".

Seiring dengan perkembangan sepakbola di Indonesia, saat ini mengalami perkembangan dan kemajuan yang cukup pesat. Munculnya klub-klub sepakbola atau Lembaga Pendidikan Sepakbola merupakan wujud dari perkembangan sepakbola di Indonesia. Dalam dunia pendidikan (sekolah), sepakbola merupakan salah satu cabang olahraga permainan yang diajarkan di sekolah yang terangkum dalam kurikulum pendidikan jasmani.

Dalam permainan sepakbola sering kita jumpai teknik-teknik dasar yang bermacam-macam. Salah satu teknik dasar yang kita jumpai adalah teknik menendang bola. Menurut Devaney (1986:30) bahwa "Seorang pemain sepakbola yang hebat, harus dapat menggiring bola, menendang bola, menerima bola, dan menembak bola (shooting), semuanya ini dikenal dengan penguasaan bola".

Menendang bola merupakan teknik dengan bola yang paling banyak dilakukan dalampermainan sepakbola. Tim yang baik adalah tim yang kemampuan masingmasing pemainnya menguasai teknik sepakbola dengan baik. Sehingga setiap pemain sepakbola harus menguasai teknik menendang bola dengan baik, cermat, cepat, dan tepat, salah satunya pada teknik passing sepakbola. Teknik passing tidak lagi hanya sebagai umpanan, tetapi sebagai serangan ke daerah lawan yang dapat menghasilkan gol. Melakukan passing dengan baik dan tepat pada sasaran bagi mahasiswa bukan merupakan hal yang mudah. Bagi mahasiswa pemula sering kali dalam melakukan passing tidak tepat pada sasaran yang diinginkan, bahkan tidak menutup kemungkinan bolanya melambung rendah. Kondisi yang demikian akan 
merugikan timnya, karena bola mudah dikuasai oleh lawan.

Kegiatan ekstrakurikuler merupakan kegiatan yang dimaksudkan sebagai wadah bagi mahasiswa untuk menyalurkan minat dan bakatnya agar bisa lebih berkembang. Di dalam kegiatan ekstrakurikuler, mahasiswa dapat memilih kegitan yang diminatinya. Salah satu ekstrakurikuler yang terdapat di kampus adalah dalam bidang olahraga. Ekstrakurikuler dalam bidang olahraga yang banyak diminati mahasiswa salah satunya adalah sepakbola. Namun, walaupun ekstrakurikuler sepakbola banyak diminati oleh mahasiswa. Ternyata dalam pelaksanaannya masih terdapat kekurangan dalam metode latihannya, sehingga kemampuan mahasiswa dalam menguasai teknik penguasaan sepakbola masih kurang maksimal. Menurut Nossek (1982: 63) yang menyatakan bahwa "metode latihan merupakan prosedur dan cara-cara pemilihan jenis-jenis latihan dan penataannya menurut kadar kesulitan, kompleksitas dan beratnya beban".

Pada kenyataan yang terjadi dilapangan, baik saat latihan maupun pertandingan, terdapat banyak kesalahankesalahan saat melakukan passing bawah yang sering tidak tepat sasaran sesuai keinginan penendang. Pada mahasiswa putra Program Studi Pendidikan Jasmani Kesehatan dan Rekreasi Sekolah Tinggi Keguruan dan Ilmu Pendidikan
Muhammadiyah Kuningan kesalahankesalahan yang sering terjadi saat melakukan passing, salah satu faktor penyebabnya adalah belum menguasai teknik menendang yang benar maka dibutuhkan cara latihan yang baik dan tepat yaitu dengan pendekatan latihan dan pendekatan bermain.

Pendekatan latihan merupakan bentuk pembelajaran suatu teknik cabang olahraga yang dilakukan dengan mengulang-ulang gerakan secara sistematis dan kontinyu. Sedangkan pendekatan bermain merupakan bentuk latihan untuk meningkatkan kemampuan passing yang dikemas dalam bentuk permainan. Selain untuk meningkatkan kemampuan teknik juga bertujuan untuk menghilangkan rasa jenuh mahasiswa dalam berlatih.

Dari pendekatan latihan dan pendekatan bermain tersebut, masingmasing memiliki kelebihan dan kelemahan, sehingga belum diketahui pendekatan mana yang lebih efektif terhadap peningkatan kemampuan passing menyusur tanah dalam permainan sepakbola. Untuk mengetahui pendekatan mana yang lebih efektif antara pendekatan latihan dan pendekatan bermain terhadap peningkatan kemampuan passing menyusur tanah dalam permainan sepakbola, maka perlu dikaji dan diteliti melalui penelitian eksperimen.

Berdasarkan latar belakang yang dikemukakan diatas, maka penulis akan melakukan penelitian dengan judul, 
"Pengaruh Pendekatan Latihan dan Bermain Terhadap Kemampuan Passing Bawah Sepakbola pada Mahasiswa Putra Program Studi Pendidikan Jasmani Kesehatan dan Rekreasi Sekolah Tinggi Keguruan dan Ilmu Pendidikan Muhammadiyah Kuningan".

\section{METODE}

Metode yang digunakan dalam penelitian ini adalah eksperimen. Tujuan penelitian eksperimen adalah meneliti ada tidaknya hubungan sebab-akibat serta besarnya hubungan tersebut dengan cara memberikan perlakuan terhadap kelompok eksperimen yang hasilnya dibandingkan dengan hasil kelompok yang diberi perlakuan yang berbeda. Dalam penelitian ini terdapat dua variabel bebas (independen) dan satu Variabel terikat (dependen) yaitu: (1) Variabel bebas (independen) dalam penelitian ini yaitu pendekatan latihan dan pendekatan bermain. (2) Variabel terikat (dependen) dalam penelitian ini adalah kemampuan passing bawah.

Subjek dalam penelitian ini adalah mahasiswa putra Sepakbola Program Studi Pendidikan Jasmani Kesehatan dan Rekreasi Sekolah Tinggi Keguruan dan Ilmu Pendidikan Muhammadiyah Kuningan sebanyak 30 mahasiswa. Uji prasyarat analisis yang digunakan dalam kelompok ini meliputi uji reabilitas, uji normalitas dan uji homogenitas. a. Uji Reliabilitas. Tingkat keajegan hasil tes yang dilakukan dalam penelitian, dilakukan uji reliabilitas dengan menggunakan korelasi interklas, ANAVA dari Mulyono B. (2010: 46-49) sebagai berikut :

$\mathrm{R}=\frac{M S_{A}-M S_{W}}{M S_{A}}$

Keterangan :

$\mathrm{R}=$ Koefisien reliabilitas

$M S_{A} \quad=$ Jumlah rata-rata dalam kelompok

$\mathrm{MS}_{\mathrm{W}}=$ Jumlah rata-rata antar kelompok

b. Uji Normalitas. Uji prasyarat analisis yang digunakan dalam penelitian ini adalah uji normalitas. Uji normalitas data dalam penelitian ini menggunakan metode Lilliefors dari Sudjana (2002: 466). Prosedur pengujian normalitas tersebut sebagai berikut :

1) Pengamatan $X_{1}, X_{2}, \ldots \ldots . X_{n}$ dijadikan bilangan baku $Z_{1}, Z_{2}, \ldots \ldots Z_{n}$ dengan menggunakan rumus :

$Z_{i}=\frac{X_{1-X}}{S}$

Keterangan :

$X i=$ Dari variabel masing-masing sampel

$\mathrm{X}=$ Rata-rata

$\mathrm{S}=$ Simpangan baku

2) Untuk tiap bilangan baku mengunakan daftar distributif normal baku, kemudian dihitung peluang $\mathrm{F}\left(\mathrm{Z}_{\mathrm{i}}\right)=\mathrm{P}\left(\mathrm{Z} \leq \mathrm{Z}_{\mathrm{i}}\right)$

3) Selanjutnyadihitung proporsi $Z_{1}, Z_{2}$, $Z_{n}$ yang lebih kecil atau sama dengan $Z_{i}$. Jika proporsi dinyatakan oleh $\mathrm{S}\left(Z_{i}\right)$, maka :

$\mathrm{S}\left(Z_{i}\right)=\frac{\text { banyaknya } Z_{1}, Z_{2} \ldots \ldots \ldots . Z_{n} \text { yang } \leq Z_{i}}{n}$ 
4) Hitung selisih $\mathrm{F}\left(Z_{i}\right)-\mathrm{S}\left(Z_{i}\right)$ kemudian ditentukan harga mutlaknya.

5) Ambil harga yang paling benar diantara harga-harga mutlak selisih tersebut. Sebutlah harga terbesar ini Lo.

Rumusnya:

$\mathrm{Lo}=\left|\mathrm{F}\left(Z_{i}\right)-\mathrm{S}\left(Z_{i}\right)\right|$ maksimum.

Kriteria :

Lo $\leq$ Lab : sampel berasal dari populasi yang berdistribusi normal.

Lo $>\mathrm{L}_{\mathrm{tab}}$ : sampel berasal dari populasi yang tidak berdistribusi normal.

c. Uji Homogenitas. Dalam uji homogenitas dilakukan dengan cara membagi varians yang lebih besar dengan varians yang lebih kecil. Menurut Sutrisno Hadi (1982: 386) rumusnya adalah :
$F_{d b v b: d b v k} \quad=\frac{S D^{2} b s}{S D^{2} k t}$

Keterangan :

$F_{d b v b: d b v k}=$ Derajat kebebasan ke 1 dan ke 2

$\mathrm{SD}^{2}$ bs $=$ Standars deviasi KE 1

$\mathrm{SD}^{2} \mathrm{kt}=$ Standart deviasi KE 2

\section{HASIL PENELITIAN}

Tujuan penelitian dapat tercapai dengan pengambilan data pada sampel yang telah ditentukan. Data yang dikumpulkan terdiri dari tes awal secara keseluruhan, kemudian dikelompokkan menjadi 2 kelompok dan dilakukan tes akhir pada masing-masing kelompok. Data tersebut dianalisis dengan statistik, seperti terlihat pada lampiran. Rangkuman hasil analisis data secara keseluruhan disajikan dalam bentuk tabel sebagai berikut :

Tabel 1. Deskripsi Data Tes Awal dan Tes Akhir Kemampuan Passing Bawah Sepakbola Pada Kelompok 1 dan Kelompok 2.

\begin{tabular}{|c|l|l|c|c|c|}
\hline Kel. & \multicolumn{1}{l|l|}{ Tes } & N & Max. Min & Mean & \multicolumn{1}{l|}{ SD } \\
\hline \multirow{2}{*}{ K1 } & Awal & 158 & 2 & 4.93 & 1.49 \\
\cline { 2 - 6 } & Akhir & 1510 & 6 & 8.06 & 1.36 \\
\hline \multirow{2}{*}{ K2 } & Awal & 157 & 2 & 5.06 & 1.33 \\
\cline { 2 - 6 } & Akhir & 1510 & 6 & 7.13 & 1.25 \\
\hline
\end{tabular}

Berdasarkan hasil pengujian perbedaan tes awal dengan $t$-test antara kelompok 1 dan kelompok 2 diperoleh nilai sebesar 1,00 dan $\mathrm{t}_{\text {tabel }}$ dengan $\mathrm{db}=\mathrm{N}-1=15-1=14$, pada taraf signifikansi 5\% sebesar 2,145. Hal ini menunjukkan bahwa $\mathrm{t}_{\text {hitung }}$ lebih kecil dari $t_{\text {tabel }}$ atau1,00<2,145. Dengan demikian dapat disimpulkan bahwa hipotesis nol diterima. Hal ini artinya antara kelompok 1 dan kelompok 2 sebelum diberi perlakuan tidak terdapat perbedaan yang signifikan antara kemampuan passing bawah sepakbola pada awalnya.

Berdasarkan hasil pengujian perbedaan tes akhir dengan t-test antara kelompok 1 dan kelompok 2 diperoleh nilai sebesar 2,712 dan $\mathrm{t}_{\text {tabel }}$ dengan $\mathrm{db}=\mathrm{N}-1=15-1=$ 14, pada taraf signifikansi 5\% sebesar 2.145. Hal ini menunjukkan bahwa $t_{\text {hitung }}$ lebih besar dari $t_{\text {tabel }}$ atau 2,712> 2,145. 
Dengan demikian dapat disimpulkan bahwa hipotesis nol ditolak. Berdasarkan hasil tersebut bahwa hasil tes akhir antara

Tabel 2 .Rangkuman Hasil Penghitungan Nilai Perbedaan Peningkatan Kemampuan Passing Bawah Sepakbola Antara Kelompok 1 dan Kelompok 2.

\begin{tabular}{|c|c|c|c|c|c|}
\hline Kel & N & $\begin{array}{c}\text { Mean } \\
\text { Pretest }\end{array}$ & $\begin{array}{c}\text { Mean } \\
\text { Postte } \\
\text { st }\end{array}$ & $\begin{array}{c}\text { Mean } \\
\text { Different }\end{array}$ & Persentasepeningkatan \\
\hline K1 & 15 & 4,933 & 8,067 & 3,133 & $63,514 \%$ \\
\hline K2 & 15 & 5,067 & 7,133 & 2,067 & $40,789 \%$ \\
\hline
\end{tabular}

\section{SIMPULAN}

Berdasarkan hasil penelitian yang telah dilakukan, dapat diperoleh simpulan sebagai berikut:(1) Ada pengaruh pendekatan latihan dan bermain terhadap kemampuan passing bawah sepakbola pada mahasiswa putra Program Studi Pendidikan Jasmani Kesehatan dan Rekreasi Sekolah Tinggi Keguruan dan Ilmu Pendidikan Muhammadiyah Kuningan, dengan $t_{\text {hitung }}=$ $2,712>t_{\text {tabel }}=2,145$.(2) Pendekatan latihan lebih baik pengaruhnya dibandingkan dengan pendekatan bermain terhadap kemampuan passing bawah sepakbola pada mahasiswa putra Program Studi Pendidikan Jasmani Kesehatan dan Rekreasi Sekolah Tinggi Keguruan dan Ilmu Pendidikan Muhammadiyah Kuningan, dengan pendekatan latihan $=63,514 \%>$ pendekatan bermain $=40,789 \%$.

Dari penelitian ini dapat diketahui bahwa pendekatan latihan dan pendekatan bermain keduanya dapat meningkatkan kelompok 1 dan kelompok 2 terdapat perbedaan yang signifikan. 
bawah sepakbola. Dalam penelitian ini, ternyata metode pendekatan latihan memberikan pengaruh yang lebih baik terhadap kemampuan passing bawah sepakbola.

Berhubungan dengan simpulan yang telah diambil dan implikasi yang ditimbulkan, maka kepada para pelatih dan khususnya para mahasiswa putra Program Studi Pendidikan Jasmani Kesehatan dan Rekreasi Sekolah Tinggi Keguruan dan Ilmu Pendidikan Muhammadiyah Kuningan, disarankan hal-hal sebagai berikut: (1) Dalam memilih jenis latihan, khususnya untuk meningkatkan kemampuan passing bawah sepakbola, hendaknya memilih jenis latihan yang lebih baik untuk meningkatkan kemampuan passing bawah sepakbola. (2) Dalam upaya untuk meningkatkan kemampuan passing bawah sepakbola, pelatih dapat menggunakan metode dengan pendekatan latihan maupun pendekatan bermain karena keduanya terbukti dapat meningkatkan kemampuan passing bawah sepakbola walaupun metode pendekatan latihan lebih baik pengaruhnya.

\section{DAFTAR PUSTAKA}

Beltasar Tarigan. 2001. Pendekatan Keterampilan Taktis dan Pembelajaran Sepakbola. Jakarta: Depdiknas. Dirjen Pendidikan Dasar dan Menengah. Dirjen Olahraga.

Devaney, John. 1986. Rahasia Para Bintang Sepak Bola. Semarang: Dahara Prize.

Mulyono B. 2010. Tes dan Pengukuran dalam Sepak Bola. Surakarta: JPOK FKIP UNS.

Nossek. J. 1982. General Theory of Training. Logos: Pan African Press.

Ramadan, G. (2017). Pengaruh Metode Pembelajaran Dan Motivasi Belajar Terhadap Hasil Belajar Passing Sepakbola. JUARA : Jurnal Olahraga, 2(1), 1-10. Retrieved from

http://jurnal.upmk.ac.id/index.php/j uara/article/view/27

Sudjana. 2002. Metode Statistika. Bandung: Tarsito.

Sugiyanto. 1995. Metodologi Penelitian. Surakarta: UNS Perss.

Sutrisno Hadi. 1982. Statistik 2. Yogyakarta: Andi Offset. 